\title{
The ancient mortars and geomaterials of tower fortification of Nora (Pula, Sardinia, Italy)
} Stefano Columbu ${ }^{\text {a }}$ Gianfranco Carcangiu ${ }^{b}$, Fabio Sitzia ${ }^{a}$

${ }^{a}$ Università degli studi di Cagliari, Dipartimento di Scienze Chimiche e Geologiche, Cagliari, Italy columbus@unica.it, fasitzia@tiscali.it, 'Consiglio Nazionale delle Ricerche - Istituto di Scienze dell'Atmosfera e del Clima, Bologna, Italy, g.carcangiu@isac.cnr.it

\begin{abstract}
The tower is located on a promontory on the south-western Gulf of Cagliari, near to the Coltellazzo island and the archaeological Punic-Roman of Nora.

The first military settlement was probably present since the beginning of the fourteenth century. Surely the tower was active since 1607. Jorge Aleo (1680) mentions, calling Fortalleza Coltellaz. In the eighteenth century the building was engulfed in a fort, built in a period of six years (1722-1728) by engineer the Piedmont Antonio Felix de Vincenti. Later (in the nineteenth century) further work was carried out until the tower became a lighthouse.

The tower was considered a tower de armas or vigorous, or for heavy defense, with a garrison of men under a commander. Being a watch tower, is in sight of the towers of Cala d'Ostia, San Macario and the Diavolo. The tower has a structure of a truncated cone, with a height of about 11 meters high and 12 meters in diameter at the base. Inside it has a double ribbed vaulted dome, supported by a central pillar.

The aim of this research is were studying mortars and geomaterials used of the ashlars, for define: i) composition of ancient mortars with ratio binder/aggregate; ii) provenance of the raw materials used in the mixture of mortars; iii) alteration processes in progress on mortars and on geomaterials used in masonry.

Through the analysis of the physical-mechanical properties, important evidences of chemical and physical decay were highlighted in the mortar of the plasters coating the tower and also in bedding mortars of ashlars of masonry. In some areas, where they are concentrated processes of physical disintegration, also as a result of dissolution of the carbonate matrix of the mortar, show scarce resistance physical-mechanical with consequent detachment from the masonry.
\end{abstract}

Keywords: Fortification, Physical decay, Chemical alteration, Nora, Geomaterials.

\section{Introduction}

The coastal tower of Coltellazzo (XVII cent.), (Fig. 1,2) situated into the Nora archaeological area, is a major maritime tower of southern Sardinia (Italy), as well as artifact of historical strategy for the island. The study of this monument is extremely useful for understanding its construction methods and the choice of geomaterials (stones and mortars) used for edification. All these information allow to direct a plan for possible restoration of the monument.
To perform the physical and petrographic characterization of geomaterials, several samples were collected from structure of tower. The sampling puts attention for the parts exposed or not to chemical and physical decay, due not only to different petrophysical characteristics of rocks, but also different micro-environmental conditions. In this article were analyzed different rock types and some constructive mortars, by applying different archaeometric study 
techniques for mineralogic-petrographic and physical characterization. This article also contains geological and geomorphological information of area's building construction and the origin of the materials used.

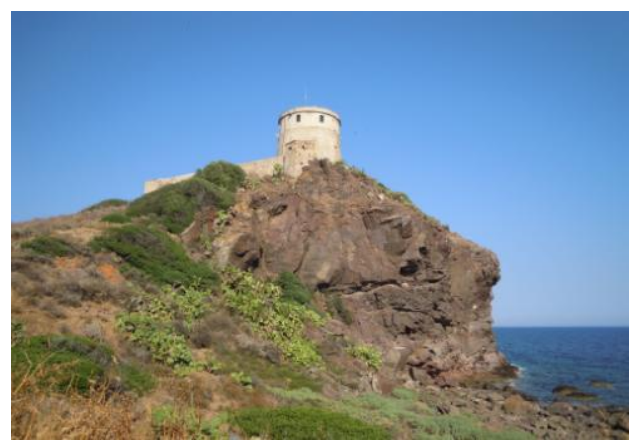

Fig. 1- The Coltellazzo tower

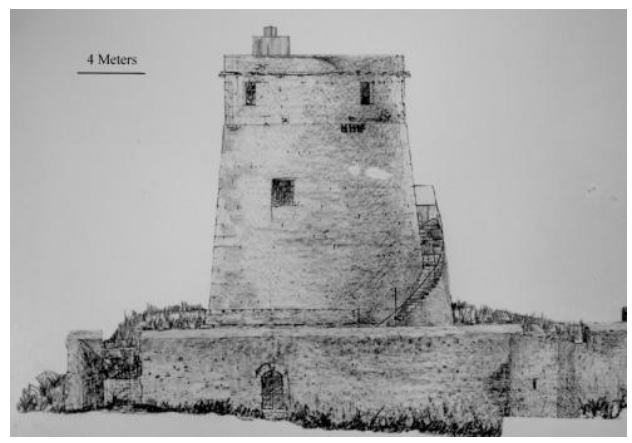

Fig. 2- Coltellazzo tower's perspective

\section{Historical informations and architecture of monument}

The Coltellazzo tower, built near the remains of the acropolis of Nora, became operational in 1607 , although the existence of a previous military settlement reached by the beginning of the fourteenth century (Rassu, 2005). Jorge Aleo, in 1680, mentions the tower, calling it as Fortalleza Coltellaz (Fois, 1981). In the eighteenth century the building was engulfed in a fort, built between 1722 and 1728 by engineer Piedmont Antonio Felice de Vincenti (Mondaldo 1992). Additional work was carried out in the nineteenth century, when the tower was equipped with a beacon. The Coltellazzo tower is architecturally similar to the nearby tower of St. Macario with column and ridges to support the vault. Coltellazzo tower is built on a hill of volcanic rock about $35 \mathrm{~m}$ high with a diameter of 14 meters (Mele, 2000). It has a conical shape with walls inclination of approximately $5^{\circ}$ (fig. $3,4)$ The height of the tower was modified than the original article at the beginning of ' 900 to allow the realization of 4 meters high volume for a beacon station (Pillosu, 1957, 1959). This structure removed some characteristic architectural elements of the original terrace caused over time several settlements of the below structure (Rassu, 2000).

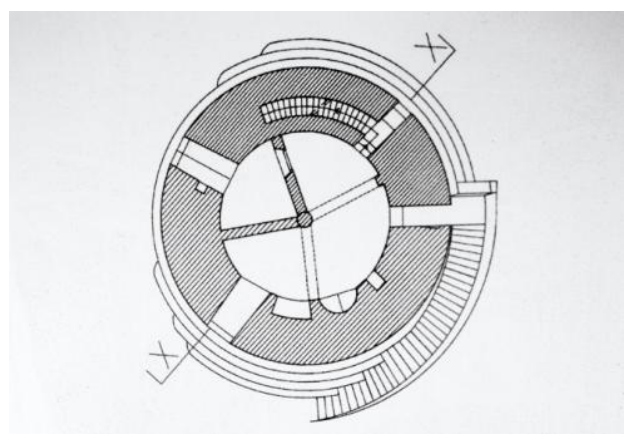

Fig. 3- Section at $\mathrm{h}=+6,20$ meters

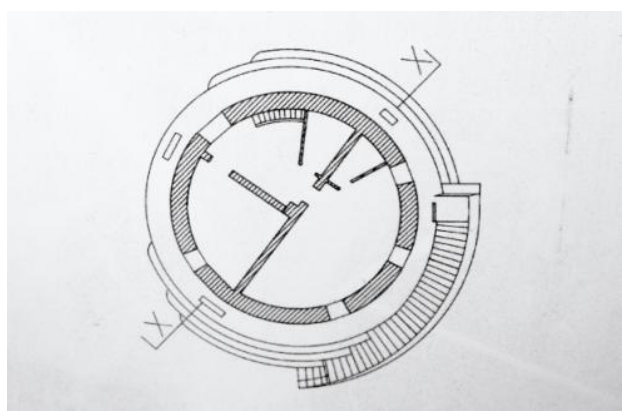

Fig. 4- Section at $\mathrm{h}=+12,00$ meters

\section{Materials e methods}

\subsection{Sampling}

The preliminary sampling was done taking on the site samples for each lithology and all kinds of mortars (i.e., bedding mortars of irregular stones and regular ashlars, plasters from outer surface of tower). They were taken 4 samples of granitoid rocks, 6 volcanic rocks (mainly woth andesitic composition), 7 sedimentary rocks (i.e., sandstone, conglomeratic rocks, etc., 
according to the particle size coarse, medium and fine), 4 samples of bedding mortars of the ashlars, 5 samples of plasters (3 of arriccio/rinzaffo layer and 2 of finiture layer) for a total of 26 samples. The sampling is occurred so as to uniformly cover the structure so as to identify any differences between samples related to different degree of alteration as function of exposure to weathering processes.

\subsection{Methods}

Petrographic determinations of mineralogical composition were carried out on polished thin sections by optical polarised microscopy Leitz Wetzlar. The physical tests were determined on specimens dried at $105 \pm 5^{\circ} \mathrm{C}$ and after the dry solid mass $\left(\mathrm{m}_{\mathrm{D}}\right)$ was determined. The solid phases volume $\left(\mathrm{V}_{\mathrm{S}}\right)$ of powdered rock specimens (on 5-8 $\mathrm{g}$ and with particle size less than 0.063 $\mathrm{mm}$ ) and the real volume (with $\mathrm{V}_{\mathrm{R}}=\mathrm{V}_{\mathrm{S}}+\mathrm{V}_{\mathrm{C}}$, where $V_{C}$ is the volume of pores closed to helium) of the rock specimens were determined by helium Ultrapycnometer 1000 (Quantachrome Instruments). Then, the wet solid mass $\left(\mathrm{m}_{\mathrm{W}}\right)$ of the samples was determined after water absorption by immersion for ten days. Through a hydrostatic analytical balance, the bulk volume $V_{B}$ (with $V_{B}=V_{S}+V_{O}+V_{C}$, where $V_{O}=\left(V_{B}-V_{R}\right)$ is the volume of open pores to helium) is calculated as:

$\mathrm{V}_{\mathrm{B}}=\left[\left(\mathrm{m}_{\mathrm{W}}-\mathrm{m}_{\mathrm{HY}}\right) / \mathrm{r}_{\mathrm{w}} \mathrm{T}_{\mathrm{X}}\right] \cdot 100$

where $m_{H Y}$ is the hydrostatic mass of the wet specimen and $r_{W} T_{X}$ is the water density at a temperature $\mathrm{T}_{\mathrm{X}}$. Total porosity $\left(\Phi_{\mathrm{t}}\right)$, open porosity to water and helium $\left(\Phi_{2} \mathrm{O} ; \mathrm{FHe}\right.$, respectively), closed porosity to water and helium $\left(\Phi_{\mathrm{C}} \mathrm{H}_{2} \mathrm{O} ; \Phi_{\mathrm{C}} \mathrm{He}\right)$, bulk density $\left(\rho_{\mathrm{B}}\right)$, real density $\left(\rho_{R}\right)$, solid density $\left(\rho_{S}\right)$ were computed as:

$$
\begin{aligned}
& \Phi_{\mathrm{t}}=\left[\left(\mathrm{V}_{\mathrm{B}}-\mathrm{V}_{\mathrm{S}}\right) / \mathrm{V}_{\mathrm{B}}\right] \cdot 100 \\
& \Phi \mathrm{H}_{2} \mathrm{O}=\left\{\left[\left(\mathrm{m}_{\mathrm{W}}-\mathrm{m}_{\mathrm{D}}\right) / \rho_{\mathrm{W}} \mathrm{T}_{\mathrm{X}}\right] / \mathrm{V}_{\mathrm{B}}\right\} \cdot 100 \\
& \Phi \mathrm{He}=\left[\left(\mathrm{V}_{\mathrm{B}}-\mathrm{V}_{\mathrm{R}}\right) / \mathrm{V}_{\mathrm{B}}\right] \cdot 100 \\
& \Phi_{\mathrm{C}} \mathrm{H}_{2} \mathrm{O}=\Phi_{\mathrm{T}}-\Phi_{\mathrm{O}} \mathrm{H}_{2} \mathrm{O} \\
& \Phi_{\mathrm{C}} \mathrm{He}=\Phi_{\mathrm{T}}-\Phi_{\mathrm{O}} \mathrm{He} \\
& \rho_{\mathrm{S}}=\mathrm{m}_{\mathrm{D}} / \mathrm{V}_{\mathrm{S}} \\
& \rho_{\mathrm{R}}=\mathrm{m}_{\mathrm{D}} / \mathrm{V}_{\mathrm{R}} \\
& \rho_{\mathrm{B}}=\mathrm{m}_{\mathrm{D}} / \mathrm{V}_{\mathrm{B}}
\end{aligned}
$$

The weight imbibition coefficient $\left(\mathrm{IC}_{\mathrm{W}}\right)$ and the saturation index (SI) were computed as:

$\mathrm{IC}_{\mathrm{W}}=\left[\left(\mathrm{m}_{\mathrm{W}}-\mathrm{m}_{\mathrm{D}}\right) / \mathrm{m}_{\mathrm{D}}\right] \cdot 100$

$\mathrm{SI}=\left(\Phi \mathrm{H}_{2} \mathrm{O} / \Phi \mathrm{He}\right)=\left\{\left[\left(\mathrm{m}_{\mathrm{W}} \mathrm{m}_{\mathrm{D}}\right) / \rho_{\mathrm{W}} \mathrm{T}_{\mathrm{X}}\right] / \mathrm{V}_{\mathrm{O}}\right\} \bullet 100$

\section{Geological and geomorphological context}

The area of the Pula-Sarroch plain, which is a coastal strip of the campidanese graben (Cherchi and Montadert, 1982), consisting of Paleozoic reliefs of eastern Sulcis. The yelding of these mountains has led to the formation of alluvial and slope deposits during the Quaternary glacis modeled along the fault surface to the east towards the sea, while downstream such deposits slope gently towards. The morphological differences are due to quaternary eustatic changes: the river terraces river to climate change. The elevations of the plain have no special heights but characterize the coastline with bays and headlands. The elevation in which Nora stands, from a geographical point of view, is originated from an ancient volcanic island connected to the mainland by a sandy pillow of modest size and shapes not particularly evident established through leveling of wind and waters.

The promontory on which the tower was built, presents a substrate made up of volcanic rocks formed by andesitic lavas and volcanic gray purple breccias belong to Oligo-Miocenic volcanic cycle occurs in Sardinia between 32-11 Ma (Beccaluva et al., 1985, 1989). La Marmora (1840), who studied this area, described volcanic rocks alternating with beddings lithologically more compact defined respectively "conglomerates" and "lava". It has also highlighted the presence of zeolites and veins of calcium carbonate and quartz. In addition to various volcanic rock types found in the Nora area it is reported also the presence of Paleozoic granitoids, sandstones and clays of Cixerri fluvial-deltaic formation and quaternary marine and continental deposits.

\section{Petrographic characterization}

\subsection{Distribution of lithologies on tower}

The structure of the tower in the basal part (stepped area) consists of a series of three steps 
made through the use of a $80 \%$ of blocks of andesite with size up to $50 \mathrm{~cm}, 15 \%$ of sedimentary rocks in blocks up to $30 \mathrm{~cm}$ and $5 \%$ of granitoids with predominantly subspherical forms probably attributable to fluvial blocks. In sloping walls used lithologies are the same than the basement but there is a higher frequency of use of sandstone $(80 \%$ of the blocks) $15 \%$ volcanic rock and a $5 \%$ of granitoids. It should be specified that in the sloping walls there is the presence of a first row (fig. 5) of square and worked sandstone blocks (side about $40 \mathrm{~cm}$ ) coming probably from the dismantling of an earlier building in the neighboring area of Nora. Over the first row until the light room instead it detects a chaotic presence of irregular stone blocks dimensionally and unworked whose size is about $1 / 5$ of the sandstone blocks of the first row (fig. 6).

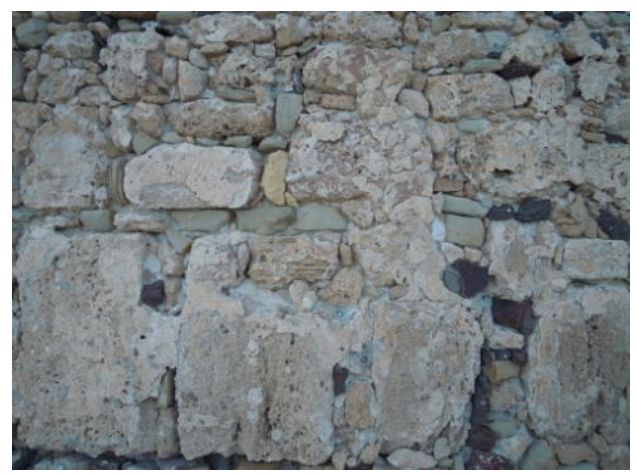

Fig. 5- First row of sandstone block

\subsection{Physical and petrographic characteristics}

The Oligo-Miocenic volcanic rocks used for the tower mainly consist in two facies. A first have mainly dacitic composition with porphiritic structure (I.P. $=8-12 \%$ ) with opaque crystals, plagioclase, orthopiroxenes, amphiboles, and \pm quarzo, \pm biotite in groudmass. This facies shows porosity value range from $18-20 \%$ in samples not altered to $20-26 \%$ in samples more altered, with values around $35 \%$ in the samples with strong physical decay by weathering. The bulk density varies from 2 to $2,1 \mathrm{~g} / \mathrm{cm}^{3}$.

The Oligo-Miocenic volcanic rocks of Sardinia were widely used in Roman period for make tools (Antonelli et al., 2014) or for construction materials. For example, are used for cavea of the Roman theatre of Nora (Melis and Columbu, 1998), near to the tower, extracting from volcanic structure of "Su Casteddu", north of Pula city.

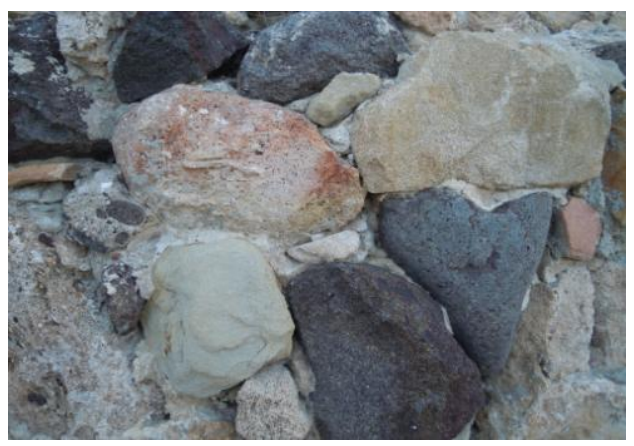

Fig. 6- Andesites, granitoid rocks and sandstones in a external wall

A second volcanic facies consists in andesites, lati-andesites, with opaque phenocrysts, plagioclase, orthopiroxenes, amphiboles (Marchi et al., 2002). These rocks have a lower porosity (ranging within 10-20\%) and so greater bulk density $(>2,1 \mathrm{~g} / \mathrm{cm} 3)$.

The sedimentary rocks show silico-clastic component with a particle size ranging from conglomerates to siltstones. The siltstones are reddish-purple and they come from a continental local formation (Cixerri). The basis of this formation was referred to the Middle Lutetian for the discovery of Carophyta and associations pollen (Pittau, 1979). Sandstones and conglomerates show quartz, feldspar, litic and andesitic clasts up to $1 \mathrm{~cm}$ of diameter. Often they have plane parallel layers and crossed lamination. The lithologies are represented by a high marine fossil content (fig. 7) (Ulzega \& Ozer 1982). These rocks are derived from the Sardinian Tyrrhenian dock (Carmigniani et al., 1982) outcropping in different parts of the Nora area. These sedimentary rocks show greater primary porosity and variable secondary porosity, due to alteration processes of "cement" matrix.

The granitoid rocks instead consist in pink leucogranite with grit from fine to medium, for the presence of large pink crystals of potassium 
feldspar and quartz. This rock is present in the high mountains northwest of Nora and belongs to the Hercynian basement. It arrives in the territory of Nora through some major rivers like Rio Pula and Rio Piscinamanna. The granitoid rocks, when not altered, have a low porosity $(<10 \%)$.

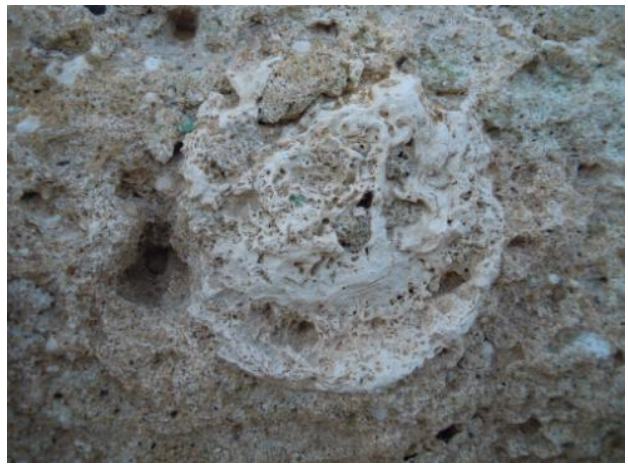

Fig. 7- Macrofossils in tyrrhenian sandstones

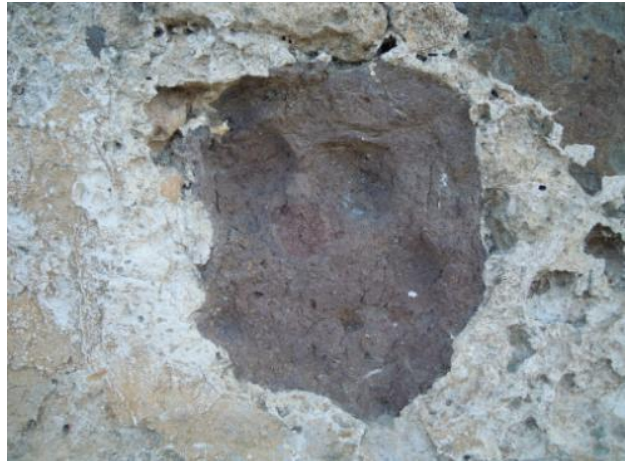

Fig. 8- Andesitic stones into bedding mortars

Original mortars in Coltellazzo tower are difficult to identify because of the massive presence of modern mortars used in recent restoration. In addition to Portland cement (Fig. 11) were used at least 3 types of modern restoration mortars. However the original mortars were sampled and divided into three main types: 1) ashlar bedding mortars (Fig. 8), 2) arriccio/rinzaffo layer plasters, 3) finiture layer plasters (Fig. 9). All the mortars have exclusively a binder with lime composition with occasionally presence of lime-lumps. However, the mortars show a medium-high degree of cohesion. The mortar aggregate consists mainly of quartz and feldspar crystals, and andesitic clasts with variable size that in the bedding mortars arrive to about $15 \mathrm{~mm}$. Binder/aggregate ratio of ashlar bedding mortars sampled is variable (range: 0,3-0,7). In the plaster the binder/aggregate ratio is approximately $0,4-0,8$.

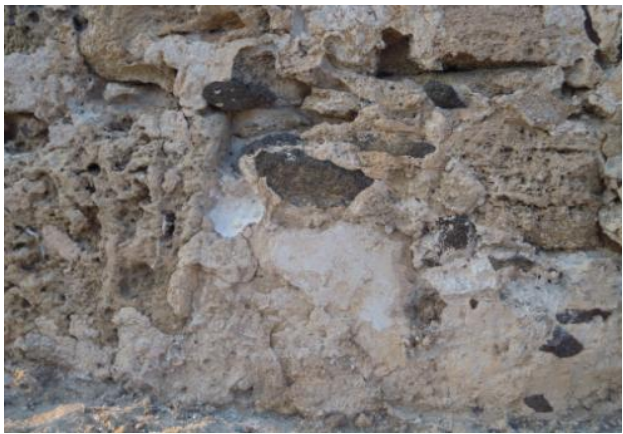

Fig. 9- External plasters

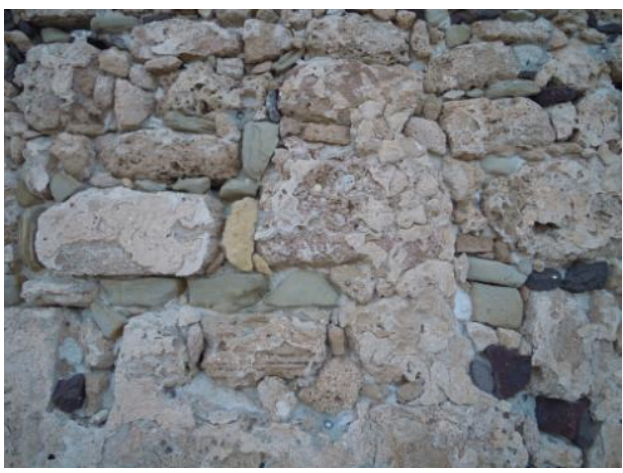

Fig. 10- Residual plasters

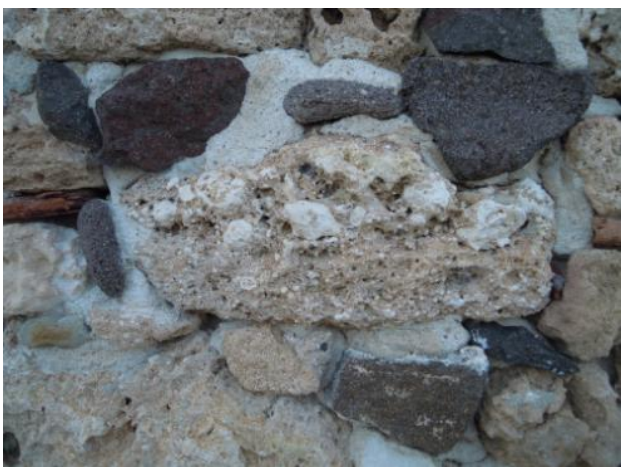

Fig. 11- Restoration Portland cement 


\section{Discussion and conclusions}

The petrographic analysis of the materials of the Coltellazzzo tower show that the lithologies used come from local geological formations as often happens in the construction of historical buildings like this. The rocks used have very different compositions. So, the variable intrinsic petrophysical characteristics of the rocks (as their porosity and the degree of cohesion) affect on their decay, determining in time different macroscopic forms of alteration, that in the case of Coltellazzo tower, considered the distance to the sea $(20 \mathrm{~m})$ are more evident.

In sandstones and conglomeratic rocks we have decohesion processes of sediment due also to dissolution of carbonate matrix, with consequently alveolation processes, mainly in the side exposed to the prevailing wind.

In the volcanic rocks with dacitic composition in some cases are detected instead advanced stages of physical decay with processes of exfoliation and flaking, often due to hydric dilatation of these rocks (Columbu et al., 2014).

The granitoid rocks and andesites present no particular problem to decay. In volcanic rocks with andesitic composition, is present occasionally exfoliation often sub-concentric to the outer surface of the ashlar, in part resulting from a pre-existing alteration. This alteration, due to marine aerosol and consequently to frequent cyclic salt crystallization-solubilization, is present mainly to the side exposed to the sea. On the side exposed to the north, are present biological patina (e.g., mosses, etc.).

The mortars of squared ashlars and irregular stone positioned in the first rows of the basal tower (mainly represented by reusing blocks of sandstone from the Punic-Roman site of Nora) are mostly a composition of lime, we do not find the presence aggregate pozzolanic. Where are the missing plaster (south side towards the sea, you can see these mortars only in depth between the segments, due to an obvious alteration.

The mortars of plaster are on the sides towards the north, while the south side, we observe various areas where missing. In this area these mortars are profoundly altered, with frequent detachment both the finishing layer, and the underlying layer of arriccio. It is evident the numerous restoration with the application of mortars recent age cement based, that certainly worsen the state of degradation generally present in the tower.

\section{References}

Antonelli F., Columbu S., de Vos Raaijmakers M., Andreoli M. (2014), An archaeometric contribution to the study of ancient millstones from the Mulargia area (Sardinia, Italy) through new analytical data on volcanic raw material and archaeological items from Hellenistic and Roman North Africa. Journal of Archaeological Science, Elsevier, Vol. 50, pp. 243-261. doi:10.1016/j.jas.2014.06.016

Beccaluva L., Civetta L., Macciotta G., Ricci C.A. (1985), Geochronology in Sardinia: results and problems. Rend. Soc. It. Min. Petr., 40, pp. 57-72.

Beccaluva L., Brotzu P., Macciotta G., Morbidelli L., Serri G., Traversa G. (1989), Cainozoic tectonomagmatic evolution and inferred mantle sources in the Sardo-Tyrrenian area. In: Boriani A., Bonafede M., Piccardo G.B., Vai G.B. (Eds.), The lithosphere in Italy. Advances in Earth Science Research. Atti Conv. Acc. Naz. Lincei, 80, pp. 229-248.

Carmignani L., Cocozza T., Ghezzo C., Pertusati P.C., Ricci C.A. (1982), Lineamenti del basamento sardo. Boll.Soc.Geol.It., Special Issue, Guida alla Geologia del Paleozoico Sardo. Guide Geologiche,. pp. 11-23.

Cherchi \& Montadert (1982), The Oligo-Miocene Rift of Sardinia and early history of the western mediterranean basin. Nature, 298, pp. 736-739.

Columbu S., Gioncada A., Lezzerini M., Marchi M. (2014), Hydric dilatation of ignimbritic stones used in the church of Santa Maria di Otti (Oschiri, northern Sardinia, Italy). Ital. J. Geosci. (Boll. Soc. Geol. It.), Vol. 133, 1, pp. 149-160.

Fois F. (1981), Torri spagnole e forti piemontesi in Sardegna. Ed. La Voce Sarda. Cagliari.

La Marmora A. (1840), Voyage en Sardaigne, II (Antiquités), Paris

La Marmora A. (1852), Itinèraire de l'ile de sardaigne, tome i-iii, Turin, Frères bocca. 
Montaldo G. (1992), Le torri costiere in Sardegna. Ed. Carlo Delfino. Sassari.

Marchi, M., Macciotta, G., Garau, A.M. (2002), Cainozoic magmatism in Sardinia and its geodynamic significance. Rend. Soc.` Paleont. It., 1, pp. 343-348.

Mele G. (2000), Torri e cannoni. La difesa costiera in Sardegna nell'età moderna. Ed. Edes. Sassari.

Melis S., Columbu S. (1998), Materiaux de construction en epoque romaine et aves les ancuennescarrieres: l'exemple du theatre de Nora (Sardaigne SO, Italie). In: La pierre dans la ville antique et mèdièval - Analyse mèthodologie et apports, Argentoun sur Creuse, France. 29-31 Marzo 1998, pp. 103-117.

Rassu M. (2000), Guida alle torri e forti costieri della Sardegna. Ed. Edes. Cagliari.

Rassu M. (2005), Sentinelle del mare. Le torri della difesa costiera della Sardegna. Grafica del Parteolla Cagliari.

Pillosu E. (1957), Le torri litoranee in Sardegna. Tipografia La Cartotecnica. Cagliari.

Pillosu E. (1959), Un inedito rapporto cinquecentesco sulla difesa costiera di Marco Antonio Camos in Nuovo bullettino bibliografico sardo e archivio delle tradizioni popolari. Cagliari.

Pittau P. (1979), Palinologia e datazione della sezione di tanca aru nella valle del cixerri. boll. soc. paleont.

Ulzega A., Ozer A. (1982), Comptes-Rendus de l'Excursion-Table rond sur le Tyrrhénien de la Sardaigne oriéntale. INQUA. p. 110. 
